\title{
The Triassic ammonite Aristoptychites kolymensis (Kiparisova) from Botneheia, Spitsbergen
}

\author{
MEIKE KÖHLER-LOPEZ AND ULRICH LEHMANN
}

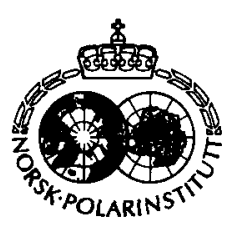

\begin{abstract}
Köhler-Lopez, M. \& Lehmann, U. 1984: The Triassic ammonite Aristoptychites kolymensis (Kiparisova) from Botneheia, Spitsbergen. Polar Research 2 n.s., 61-75.

Aristoptychites kolymensis (Kiparisova) is investigated and described in detail from collections made at Botneheia, Spitsbergen, where it occurs at the top of the Botneheia Formation (Daonella Shale). It is a rather small species and the stratigraphically highest representative of the genus in Spitsbergen. Its suture line is remarkable by its possession of the additional $\mathrm{U}_{\mathrm{n}}$-lobes between the internal lobe and the first umbilical lobe. A lobe of this kind has so far been described only once, with Arcestes (Proarcestes) bicarinatus by Schindewolf (1968), which suggests affinities between Ptychitidae and Arcestidae.
\end{abstract}

Meike Köhler-Lopez and Dr. Ulrich Lehmann, Geologisch-Paläontologisches Institut und Museum der Universität Hamburg, Bundesstrasse 55, D-2000 Hamburg 13, Germany; April 1983 (revised September 1983).

\section{Introduction}

\section{Geological background}

The ammonites described in this paper were collected in 1968 and 1972 on Botneheia, Spitsbergen, by U. Lehmann and H.-J. Lierl. The position of the collecting area is shown in Fig. 1. The Botneheia mountain is a $500 \mathrm{~m}$ high plateau situated on the southern shore of Isfjorden. It slopes steeply towards the fjord and more gently towards the east and west. Its geographical position is approximately $78^{\circ} 20^{\prime} \mathrm{N}$ and $16^{\circ} 25^{\prime} \mathrm{E}$. In the profile exposed on the northern slope, the steepest section is formed by the black, bituminous Daonella shales. The situation has been described by Frebold $(1931,1935)$. In his profiles 3 and 4 on Botneheia (1931:33), he mentioned paper-thin black shales, about $50 \mathrm{~m}$ thick, forming a very steep slope (Black Daonella shale), topped by marly shales about $10 \mathrm{~m}$ thick (Daonella marl).

In the uppermost part of the Daonella shale, a layer of calcareous nodules is found which contains numerous specimens of Aristoptychites, together with the bivalve Daonella degeeri Böhm. In profile 3 , the nodules are situated $250 \mathrm{~m}$ above sea level, descending to $180 \mathrm{~m}$ in profile 4 . We started collecting behind the Botneheia hut and followed the outcrop for about 3 kilometres. We collected more than a thousand specimens of mostly small size, the largest ones measuring $6 \mathrm{~cm}$ in diameter. The living chambers are always crushed as are many phragmocones. For exact measurements and for investigation of the onto- genetic development of the suture line, only about 150 specimens could be used.

The fossiliferous layer may, in places, consist of a bank of limestone, but more often there are only more or less well isolated calcareous nodules, merging into marly sediment.

The stratigraphical position of the fossiliferous nodule layer was considered as upper middle Triassic by Frebold; Buchan et al (1965) considered it as uppermost part of their Botneheia Formation and probably uppermost Anisian. Tozer \& Parker (1968) placed the upper part of

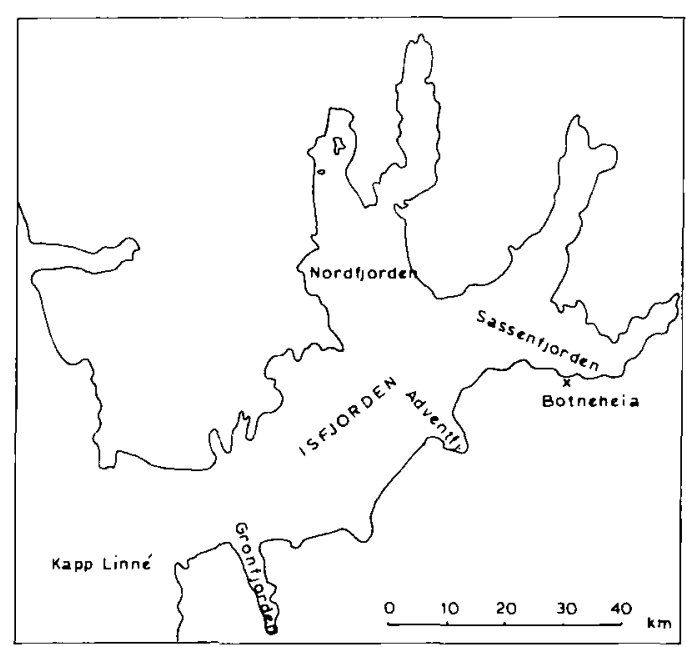

Fig. 1. Map of the Isfjorden area showing the position of Botneheia. 


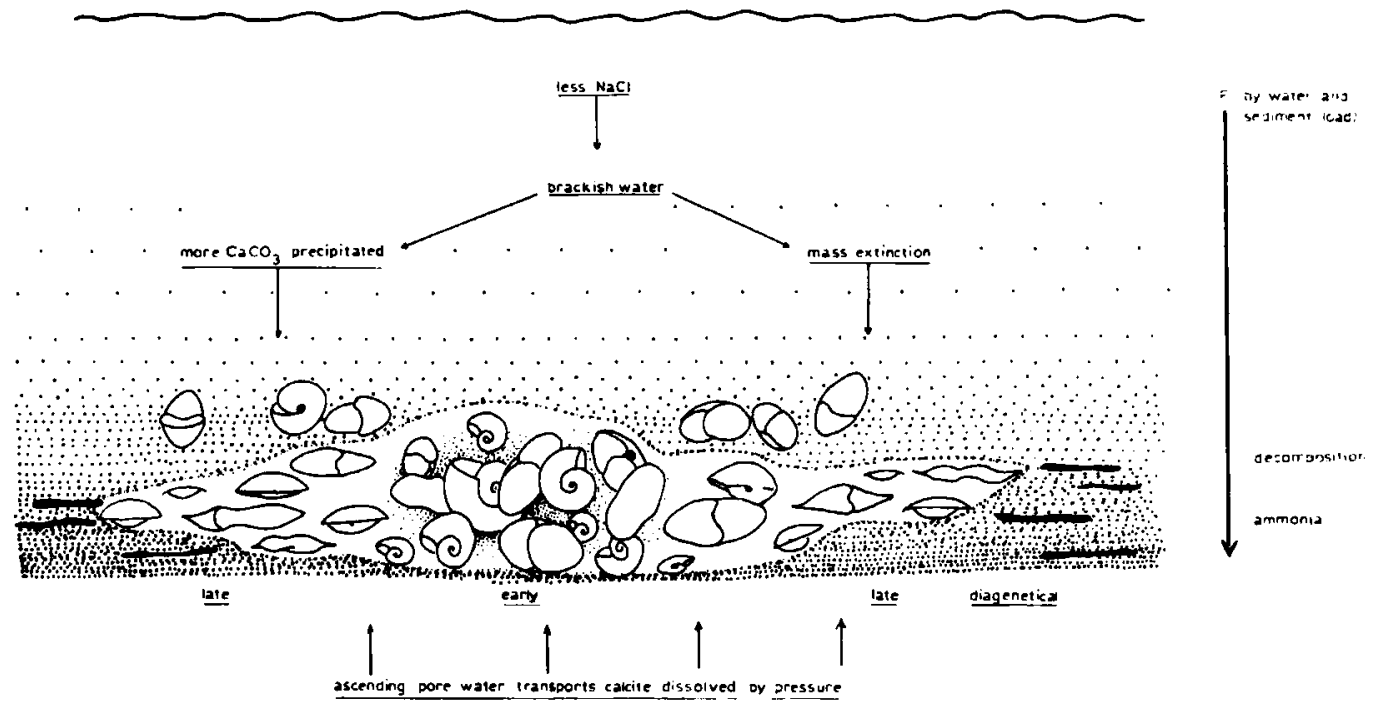

Fig. 2. Diagram suggesting environmental conditions during fossilisation at the investigated horizon.

the Botneheia Fm. in the Ladinian, because it contains Nathorstites and, in the marls above the Aristoptychites bed, Protrachyceras, besides the Aristoptychites described in this paper. Further attempts at more precise dating of the Triassic sequence were started by Weitschat \& Lehmann (1978) and will be continued.

The specimens of Aristoptychites dealt with in this paper are the stratigraphically highest known from Spitsbergen. The specimens found below that level will be treated in a forthcoming paper.

\section{Preservation}

The Botneheia profile is dominated by the high Daonella Shale escarpment, a dark-grey, in places bituminous paper shale with countless impressions of the bivalve Daonella and flattened specimens of Ptychites. The upper edge, towards the Tschermakfjellet Formation contains a horizon with large limestone concretions sometimes full of Aristoptychites specimens.

The fossiliferous layer may, in places, consist of a bank of limestone, but more often there are only more or less circular calcareous nodules which merge into marly sediment laterally. In most cases they are caudate, i.e. marginally flattened. In the fresh state, concretions and matrix are deep-black, in places with concentrations of asphaltic substance. Besides the bivalve Daonella, the concretions contain many specimens of the genus Aristoptychites and small numbers of the genera Ussurites and Nathorstites. The Aristoptychites were embedded in various positions, vertically (Plate 1, Figs. 1, 3, 4) as well as obliquely (ibid., Fig. 2) or horizontally (ibid., Figs. 5-8). The living chambers are never intact, but crushed at least in the apertural region. In most cases, the preservation of the phragmocones is much better; they are normally filled with clear calcite. The deformation of the specimens increases gradually from the centre to the margins of the concretions. The preservation of the inner whorls, including the protoconch, of the septa and of the suture lines is remarkably good.

In many cases, the shells show water levels (libellas) which consist of cavities partly filled with sediment. They may be found in the living chambers and in the umbilical opening (Plate 1, Fig. 6). The cavity above the sediment level is secondarily filled with calcite. Libellas of this kind indicate the position of the shell within the sediment. They are probably caused by gases formed in the sediment.

The concretions themselves are assumed to have been developed close to the sediment surface of a nearly anaerobic putrid calcareous mud. This is not inconsistent with the presence of bivalves, for the Daonellas probably lived above the bottom surface, either swimming or attached to algae. The development of the concretions started in an area with little overburden, since they show 
hardly any compression in their centres. Approaching the marginal areas, however, compaction increased, as shown by the broken ammonite shells and the tailed margins. The pressure caused various kinds of deformation of the ammonite shells: when embedded vertically, the living chambers burst radially, the upper half tilted over the lower one (Plate 1, Figs. 1-4); when embedded horizontally, the living chambers show numerous concentric fissures and are usually pressed flat - the shells then appear tailed off (Plate 1, Fig. 8). If the pressure is not absorbed completely by the living chamber, the phragmocone may also be deformed. In that case, the whorls break up medially and are tilted over as described above (Plate 1, Fig. 7). Considering the almost globular shape of the ammonites, the compaction pressure must have been considerable.

The size of the shells varies much $(1-60 \mathrm{~mm})$ and they show no sign of wear, which suggests autochthonous embedding.

The fossil-bearing horizon is rich in individuals but poor in species. The presence of large numbers of bivalves indicates less than $100 \mathrm{~m}$ depth. On account of the fine-grained matrix and the anaerobic conditions, the water must have been rather quiet. We assume, therefore, that the fossils were deposited in the central parts of a shallow, relatively narrow epicontinental sea. The biotope in this area was not very favourable, for living conditions were in an uncertain balance. It seems probable that a sudden catastrophe caused extinction of the fauna. The large number of fossils as compared to the overlying and underlying strata, the change in facies from the calcareous nodules to the overlying marl layers and the large number of very small shells all seem to indicate a sudden change of environmental conditions. This possibly catastrophic event was induced by a reduction in salinity, leading to brackish water.

\section{Palaeontology}

Family PTYCHITIDAE Mojsisovics 1882

Aristoptychites Diener, 1916

Aristoptychites kolymensis (Kiparisova 1937)

Ptychites kolymensis: Kiparisova 1937, p. 166, pl. 4, fig. 3

Ptychites nanuk: Tozer 1961, Buchan et al. 1965, p. 81
Ptychites sp.: Tozer \& Parker 1968, pl. 27, fig. a Aristoptychites kolymensis (Kiparisova): Vavilov \& Alekseyev 1979.

\section{Description}

In juvenile specimens, the shell is globular: as high as it is wide. Starting with a diameter of $15-20 \mathrm{~mm}$, the shells become more slender. The largest specimen at our disposal is $5.95 \mathrm{~cm}$ in diameter and $3 \mathrm{~cm}$ in width; this means that the relationship of diameter to width changes from $1: 1$ towards $2: 1$. The most remarkable feature is the shape of the flanks. Only in juvenile stages are they highly convex, but even then, they run roof-like towards the venter. Later they become nearly plane.

Juvenile stages show no trace of sculpture up to a diameter of $1-1.5 \mathrm{~cm}$. Slowly, 15-18 wide, radial folds per whorl develop which may be inclined slightly towards the aperture. The distinctness of the folds varies. They disappear towards the venter, which may appear almost smooth.

The umbilical width varies very much. The umbilical edge is rounded and slopes steeply or somewhat obliquely to the umbilicus.

The length of the living chamber may amount to $450^{\circ}$. The maximal size is not known, no adult specimens could be identified.

The suture line varies much in the degree of incision, but not in the number of elements. All saddles are compressed at their base and the saddle peaks are split by an incision. In larger specimens, the incision of the saddles situated close to the umbilicus may become so deep that they may be mistaken for neighbouring U-lobes. The lateral saddle (see Fig. 13) is extremely small and narrow. The lobes appear trifid, only the internal lobe is bifid.

\section{Detailed investigations}

Cross section. - In a large number of specimens, the cross section shows three growth stages (Fig. 3).

1. The first growth stage comprises the first 1.5 to 2 whorls. During that stage, the height of the chambers increases, but not the width of the shell.

2. Up to the 7th or 8th whorl, the shell widens considerably. The cross section is more oval 


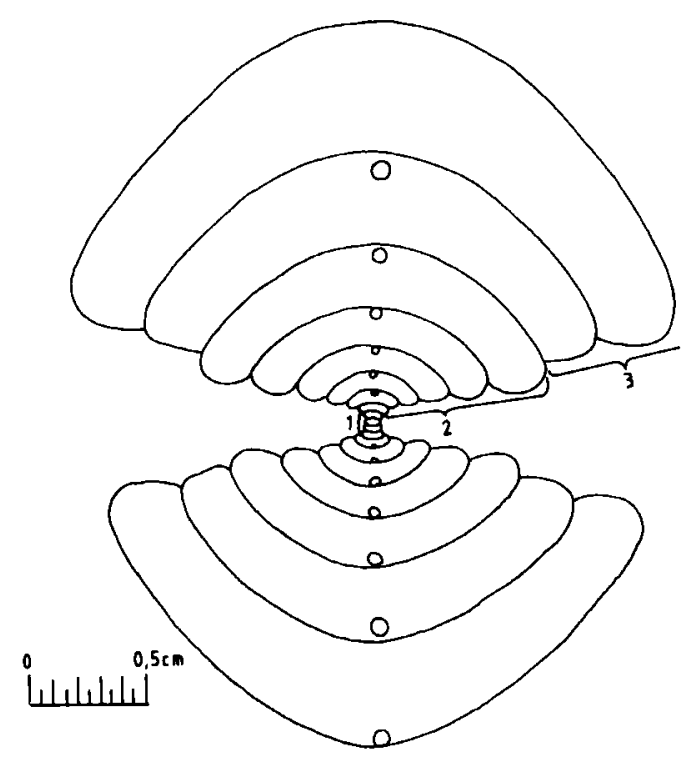

Fig. 3. Cross section of a specimen of $A$. kolymensis showing the growth stages described in text.

than circular. The umbilical flank is slightly convex, the umbilical rim is rounded.

3. After the 8th whorl, the shell flanks are nearly plane, the venter begins to protrude, the umbilical flank slopes steeply and the whole

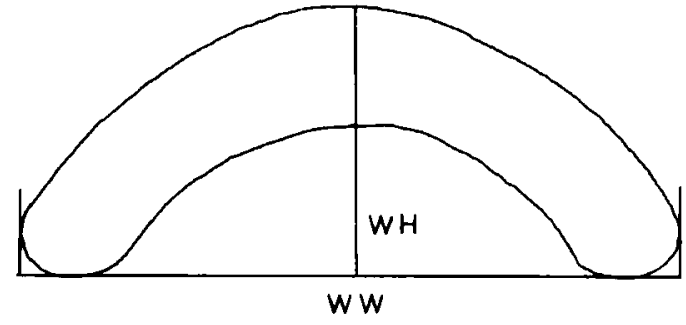

Fig. 4. Diagram indicating method of measuring.

cross section becomes more oval. It is important to note the fastigate shape, especially in later stages. It served well to differentiate this species from the older Spitsbergen species of Ptychites.

Ratio height to width. - Our material varies considerably as concerns height and width of the whorls. The ratio of both measurements during ontogeny was therefore compared in 28 selected cross sections. The height of the whorls was measured perpendicular to a line connecting the flanks of an air chamber (Fig. 4). For accuracy, measurements were started beyond the completed second whorl.

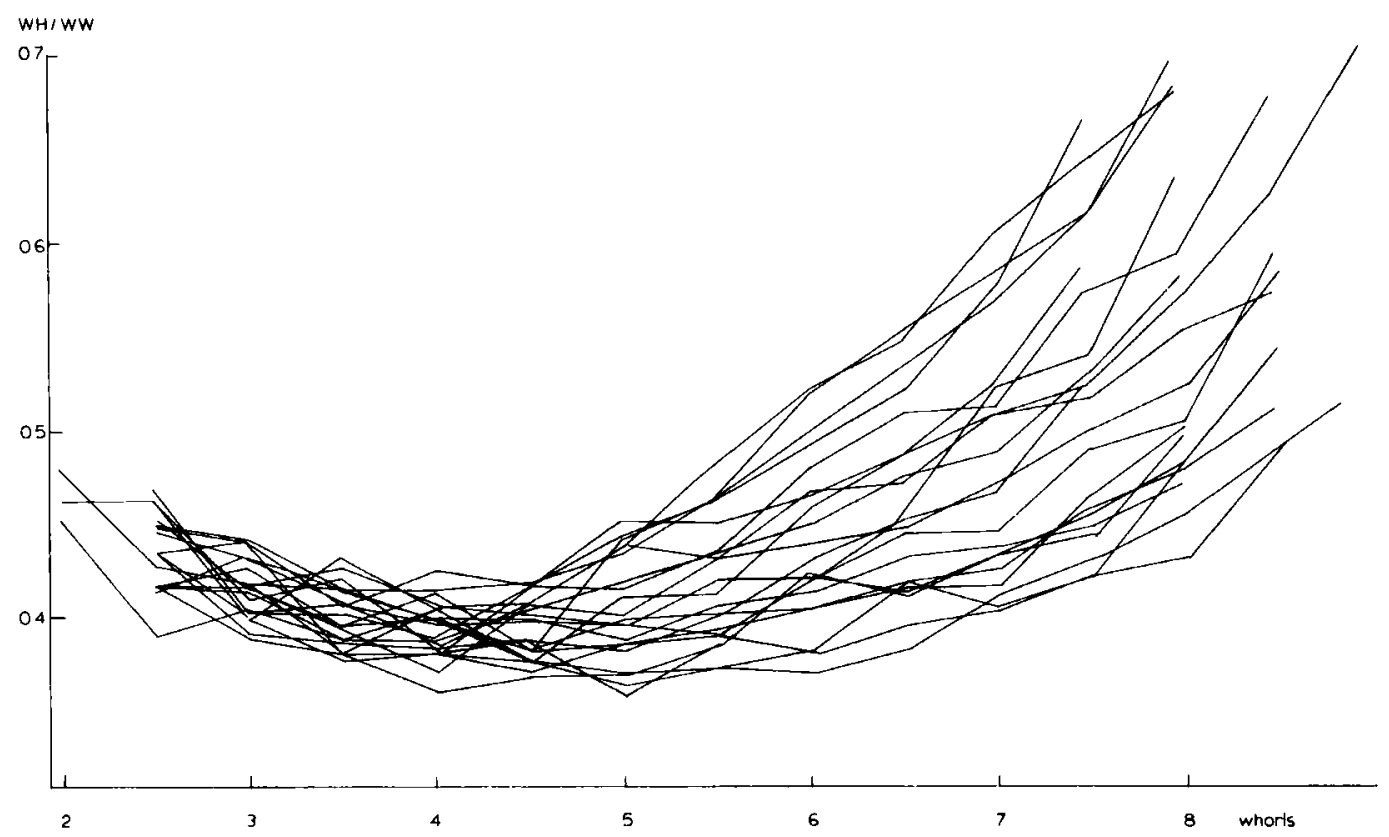

Fig. 5. Height/width ratio of whorls in relation to number of whorls. 
The early evolution up to the beginning of the sixth whorl (Fig. 5) shows no remarkable spreading of measurements. The ratio whorl height/ whorl width changes gradually from $\mathrm{W}_{h} / \mathrm{W}_{\mathrm{w}} \cong$ 0.475 at the beginning of the third whorl to $\mathrm{W}_{\mathrm{h}}$ $\mathrm{W}_{\mathrm{w}} \cong 0.39$ at the beginning of the fifth whorl. Around the beginning of the sixth whorl, the ratio stagnates, the specimens becoming larger without changing this ratio. Thereafter, the values vary increasingly, but so regularly distributed that no groupings are discernible.

If only whorl height and whorl width measurements are considered without regard to the number of whorls, the result is quite similar: increasing variation without groupings, without the possibility to separate, for instance the 'thick' specimens from the 'slender' ones, quite in contrast to the general impression.

An average growth curve deduced from the values of the specimens is produced in Fig. 6.

Septal distance. - The distances between the septa were measured in median sections of 14 specimens and the results are shown diagrammatically in Fig. 7. The measurements were taken in the area of the siphonal necks.

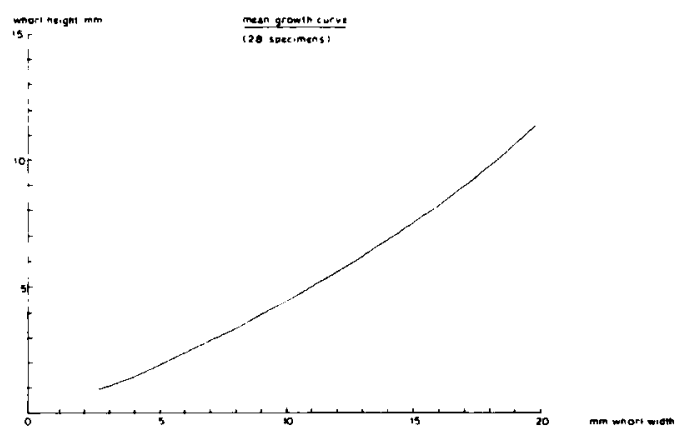

Fig. 6. Mean growth curve (28 specimens), ratio whorl height/whorl width.

The distance between the first and second septum is between 0.05 and $0.1 \mathrm{~mm}$; it then rises to 0.3 to $0.6 \mathrm{~mm}$ up to the end of the first whorl where the 'nepionic constriction' of Birkelund (1967) occurs. The number of septa in the first whorl is $6-10$. The next $2-3$ septa are closer together, the height of the chamber decreases by $0.1 \mathrm{~mm}$. The second whorl contains 7-11 septa, their distance rises to $0.4-0.6 \mathrm{~mm}$. The third whorl has 9-13 septa, their distance is $0.6-0.8 \mathrm{~mm}$. The



Fig. 7. Distance of septa. Small numbers: numbers of whorls. Underlined numbers: collection numbers of specimens. 
fifth whorl ends with a total number of septa around 55 , their distance is then $1.5 \mathrm{~mm}$.

At this point, a considerable variation begins, as is well visible in the diagram.

In none of the specimens (secondary) was approximation of septa observed, which often indicates the end of growth and thus the adult stage. This may mean either that all the specimens from the horizon were juvenile, or that this species did not have a definite end of growing at all. Even a specimen with $6.7 \mathrm{~cm}$ radius (in another horizon, though) does not have any observable approximation of septa, and even very much larger alpine species of Ptychites do not regularly have approximated septa.

Shell thickness. - In some specimens, the shell seems to be excessively thick externally in the seventh and eighth whorls. This caused us to measure the thickness of the shell in median sections of nine specimens, measuring at angles of $90^{\circ}$ to the shell surface (Fig. 8).
In the first whorl, the shell is 0.001 to $0.002 \mathrm{~mm}$ thick, in the constriction it reaches $0.004 \mathrm{~mm}$, diminishing again behind it to $0.002 \mathrm{~mm}$. It increases gradually to $0.006 \mathrm{~mm}$ at the end of the fifth whorl. In the sixth whorl, the thickness starts varying very much, reaching $0.015 \mathrm{~mm}$ in most specimens, but up to $0.025 \mathrm{~mm}$ in three unusually slender specimens. Generally, the more slender specimens show a larger amount of variation in shell thickness than the broader ones. The increase in shell thickness, in three cases, is restricted to the external side, whereas in the broader specimens the whole shell increases in thickness.

Spiral coiling. - Ammonites are coiled in a logarithmic spiral. Following the method suggested by Haarländer (1952), the equation of the spiral is given as $c=\frac{2 \ln q}{\pi}$, if the radii are measured every $90^{\circ}$ ( $c=$ spiral constant; $\ln =$ logarithmus naturalis; $q=$ quotient of two successive radii; $\pi=90^{\circ}$ ).

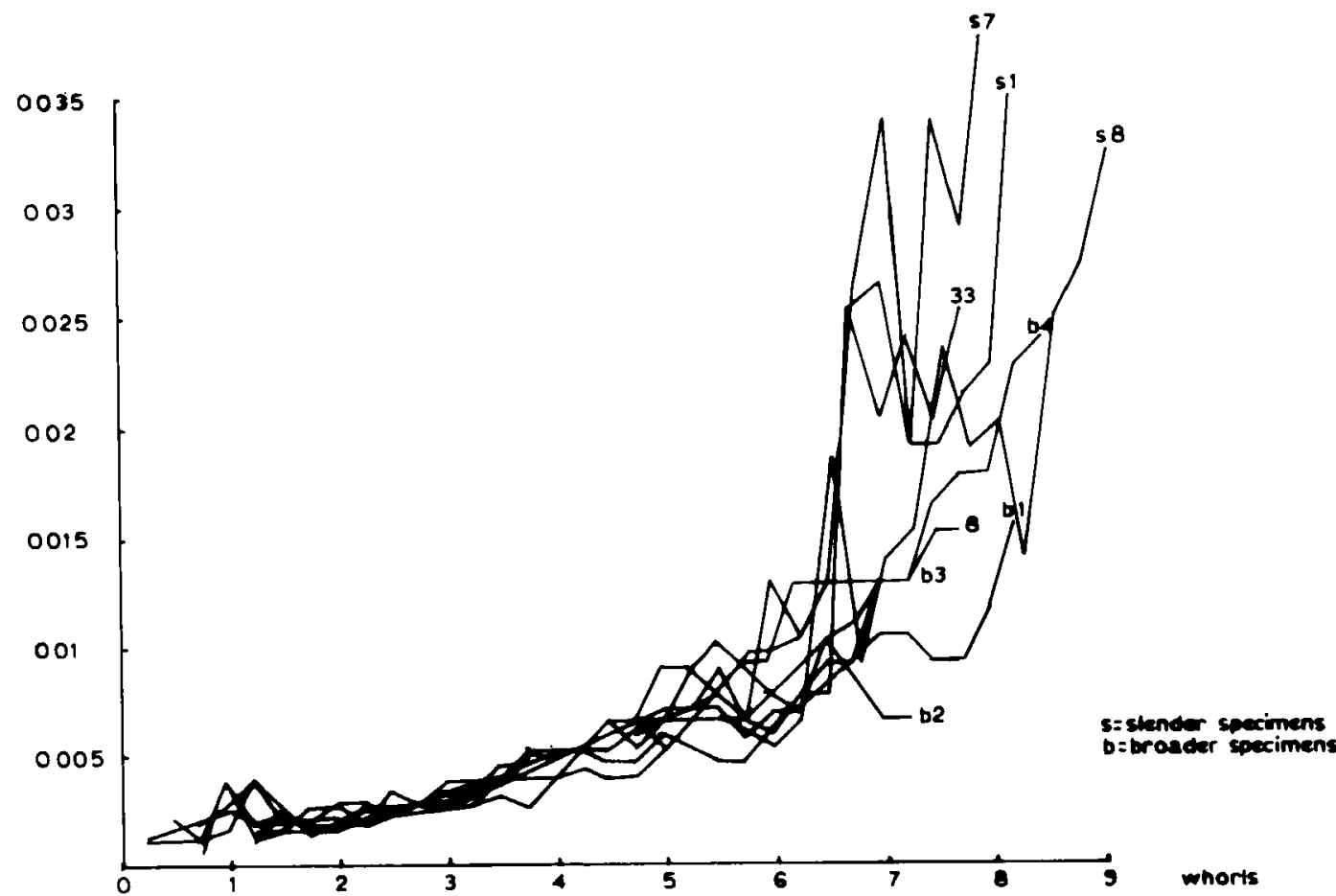

Fig. 8. Shell thickness in relation to number of whorls. Figures: collection numbers. 


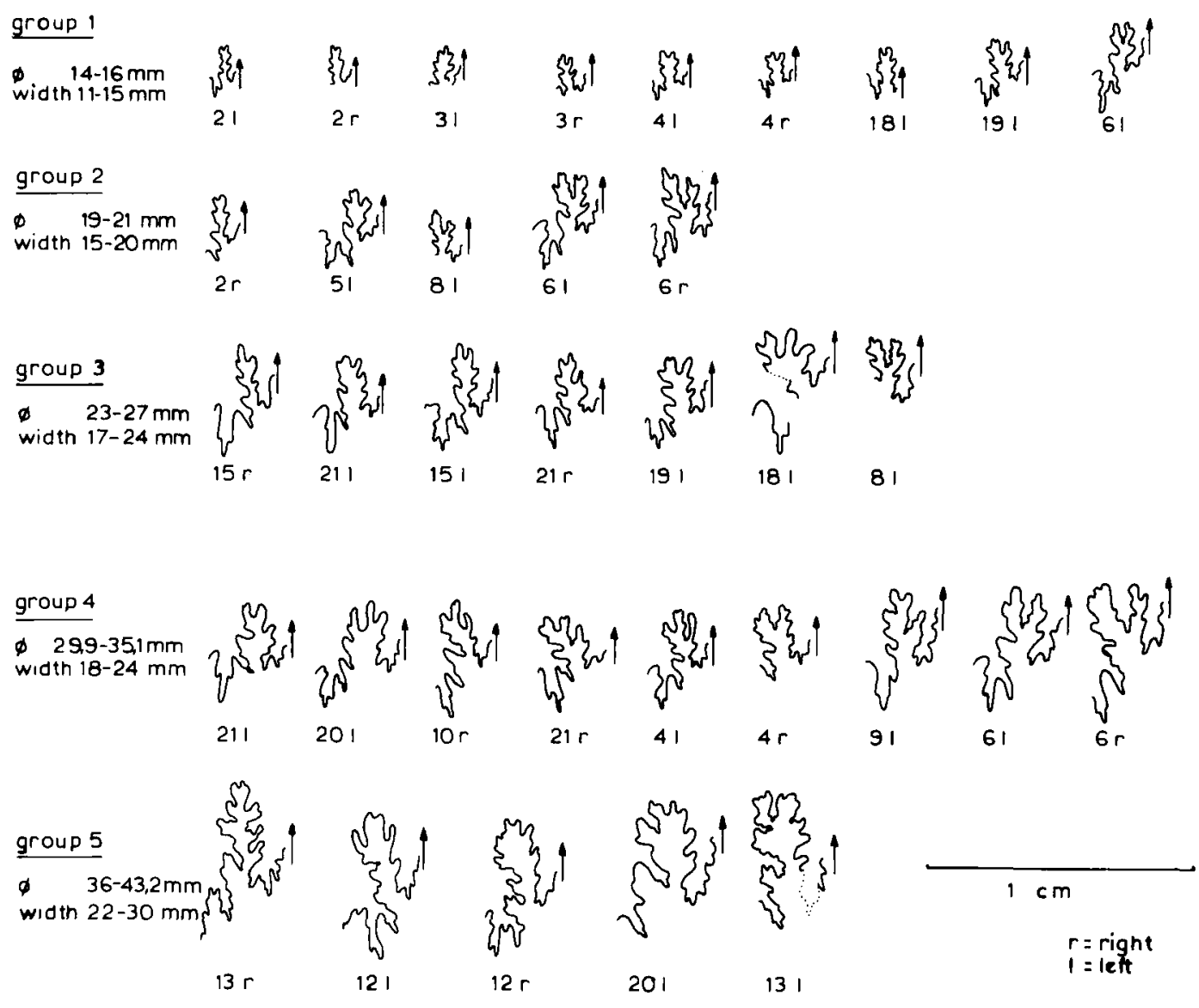

Fig. 9. External lobe and lateral saddle of 15 specimens in different size groups, showing size increase from left to right of the lateral saddle incision. The right halves of the suture lines are drawn in reflection to facilitate comparison.

In nine measured specimens, the value of $c$ was very regularly 0.07 from the second to the seventh whorl, with no indication of an alteration towards the last whorl.

Suture line. Remarks on variability. - The variability of individual sutural elements is considerable; it is important to differentiate between normal variation and structural differences.

To this aim, a diagram has been drawn which allows direct comparison of external lobes and lateral saddles in various stages of development (Fig. 9). Fifteen specimens are shown, arranged in five size groups. In each group, the size of the lateral saddle incision increases from left to right. The variation reaches from lateral saddles almost without incision (group 3, No. 15 right; group 5, No. 13 right) through all intermediate stages to saddles with very deep incisions (group 3 , No. 8 ; group 4, No. 6).

In many cases, not even both sides of one suture line are identical. An example is the suture line of No. 6, Fig. 10, in which the incision of the lateral saddle appears earlier at the right side and becomes stronger ontogenetically.

In view of the wide variation of single suture line elements, some doubt arises concerning the incision of the first saddle in Ptychites nanuk Tozer as a diagnostic specific feature (Tozer 1961). An incision of this kind was observed and drawn by Mojsisovics (1885) at the paratype of Ptychites lundgreni Mojs. It is also clearly visible in the Spitsbergen species described here.

Our conclusion is that the suture lines within our material are basically identical. The large variation within individual sutural elements 


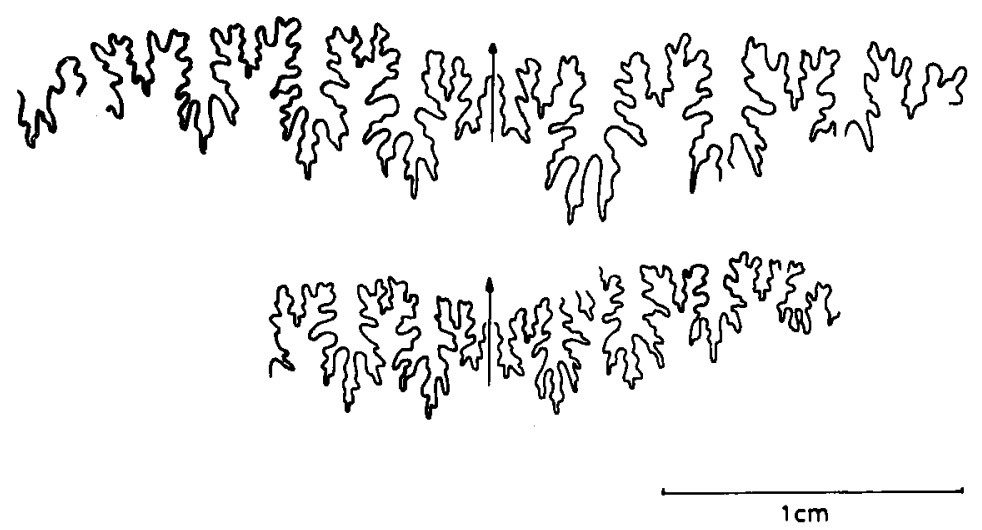

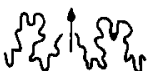

$$
\begin{aligned}
& \text { mits? }
\end{aligned}
$$

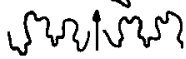

$$
\begin{aligned}
& \text { nitors }
\end{aligned}
$$

Fig. 10. Right and left half of suture line in specimen No. 6.

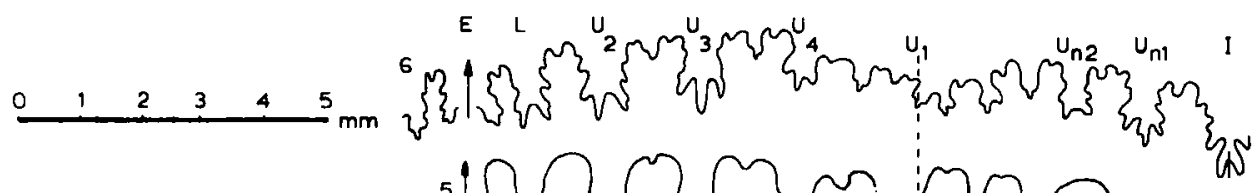

22

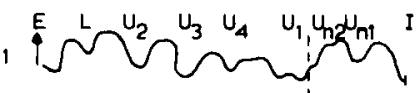
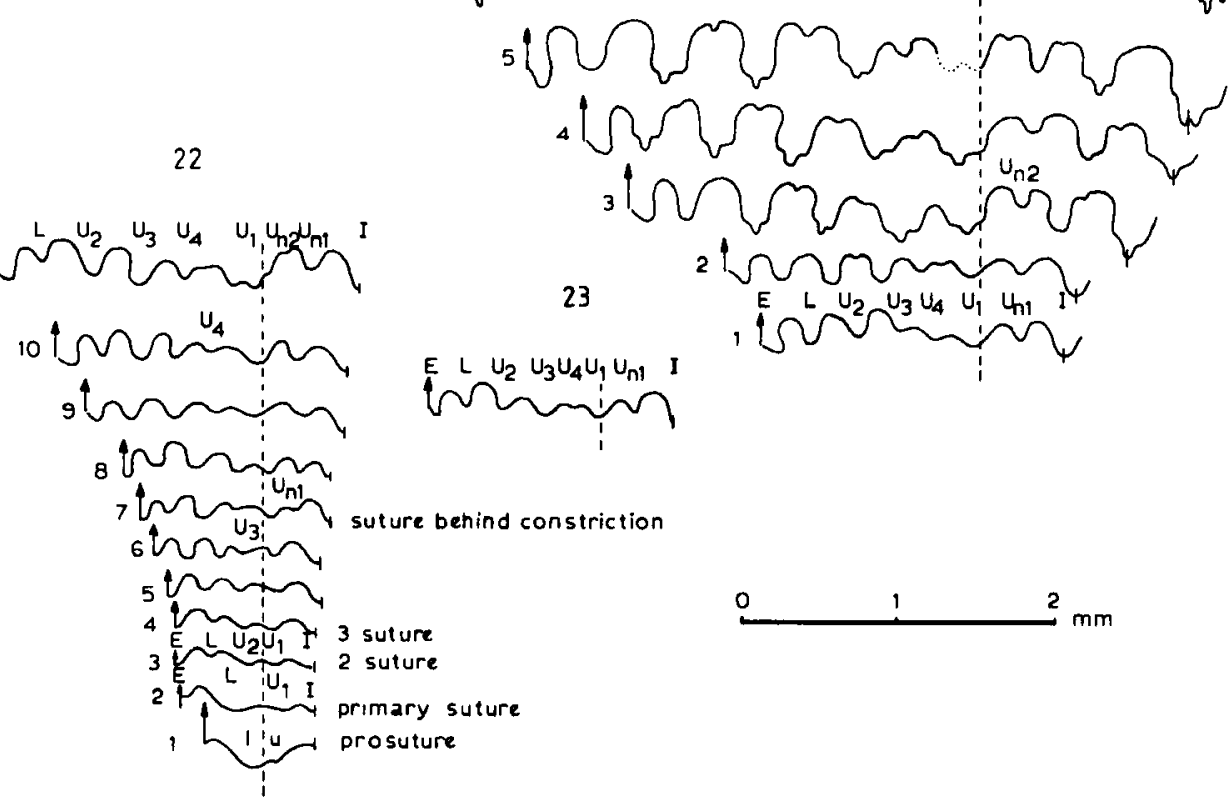

Fig. 11. Ontogenetic sequence of suture lines of specimen Nos. 11 and 22, single suture line of specimen No. 23. 


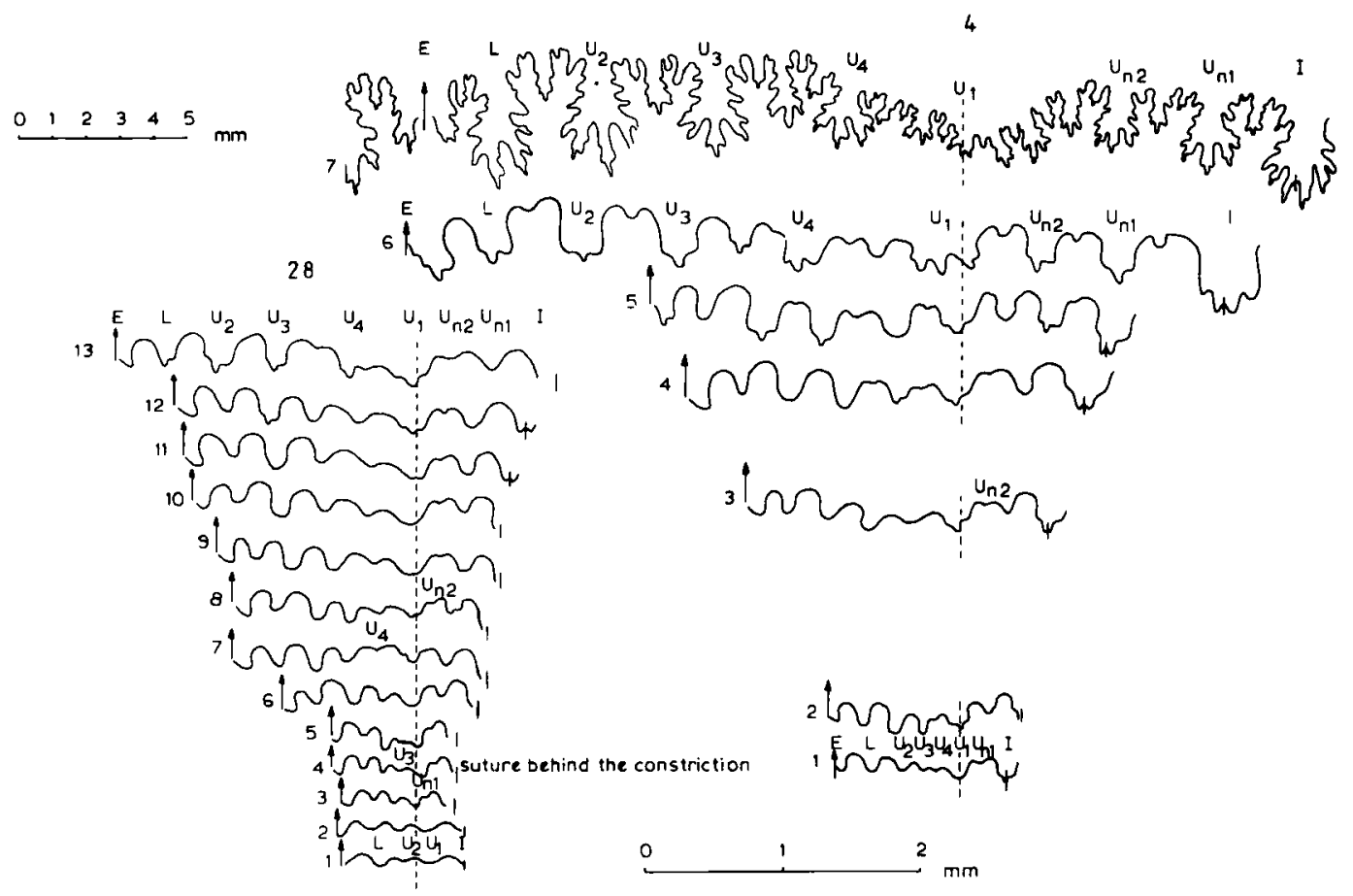

Fig. 12. Ontogenetic sequence of suture lines of specimen Nos. 4 and 28.

proves that the suture line cannot be used for specific, possibily not even for generic identification, unless the degree of variability is well known.

Suture line. Ontogenetic development. - In order to observe the ontogenetic development of the suture line, the suture lines of eight specimens were drawn. Since this was accomplished by means of a drawing-mirror, slight distortions may occur. An ontogenetic sequence of suture lines is given for four specimens (Nos. 4, 11, 22, and 28) and a single one (No. 23) in Figs. 11 and 12. The other, incomplete, suture lines are snapshots out of the development of different specimens and are only supposed to serve for comparison.

Of ten additional specimens, Scan-photos were taken which show various stages in early ontogeny. The prosuture is shown in Fig. 11; it is also very visible in Plate 3, Figs. 1, 2, 3, 4. It is latisellate, with a wide external and internal saddle. Between these two saddles there is one lobe each externally and internally, especially visible in Plate 3, Fig. 1. The external lobe is clearly larger than the internal one. By its position and size it is the lateral lobe 1 , the smaller one is the first umbilical lobe $\mathbf{u}_{1}$. Following Wiedmann \& Kullmann (1981), we label them by small letters, so they cannot be mistaken for the lobes of the 'real' suture lines. The next suture line is the quadrilobate primary suture, it is the first 'real' one. Its formula ELU $\mathrm{U}_{1}$ is typically that of Triassic ammonoids. In the second suture line (Fig. 11, No. 22, Plate 3, Figs. 3, 4) the $U_{2}$ appears already between the lateral lobe and the first umbilical lobe $U_{1}$. While the two umbilical lobes increase in size, the lateral lobe narrows (Fig. 11, No. 22/3-5; Fig. 12, No. 28/1-3). At the end of the first whorl, the $U_{3}$ arises between $U_{2}$ and $U_{1}$ at the umbilical seam (Fig. 11, No. 22/6; Fig. 12, No. 28/4) and soon enlarges. Almost simultaneously a new lobe arises at the saddle peak between the internal lobe and the umbilical lobe $\mathrm{U}_{1}$ (Fig. 11, No. 22/7; Fig. 12, No. 28/3). A lobe of this kind has been described and discussed at length by Schindewolf $(1968: 413 \mathrm{ff})$ as a feature of the Stephanocerataceae. A similar structure was observed by him (1968:821 ff.) in Proarcestes bicarinatus (Mstr.), but in this case, even two lobes were built at this place one after the other. 


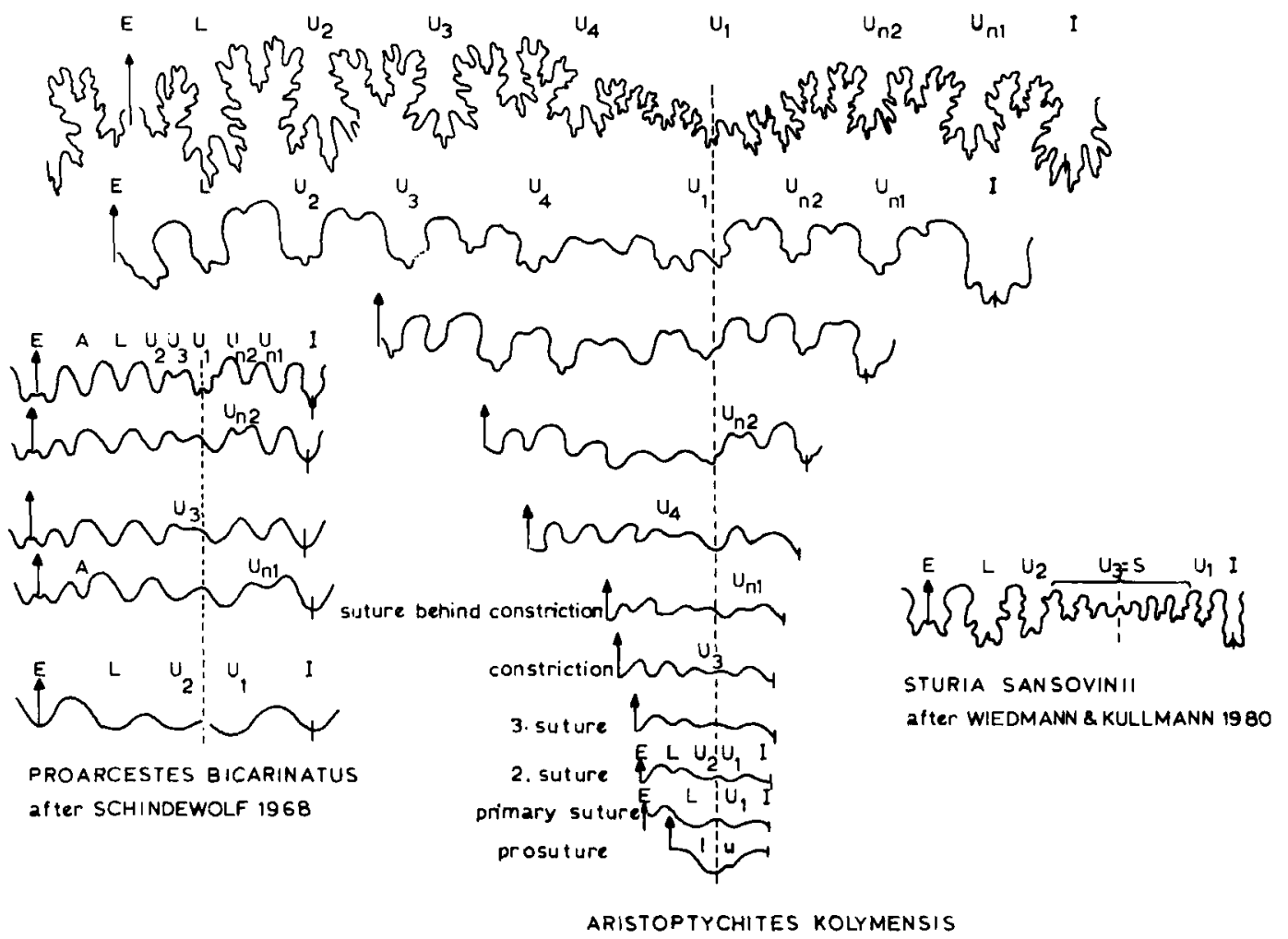

Fig. 13. Ontogenetic sequence of suture lines of Proarcestes bicarinatus (Mstr.) and Aristoptychites kolymensis, both showing $\mathrm{U}_{n 1}$ and $\mathrm{U}_{n 2}$; single suture line of Sturia sansovinii with $\mathrm{U}_{3}$ developed as a sutural lobe.

He labelled lobes of this unusual kind $\mathrm{U}_{n}$, the letter $n$ signifying an indifferent numerical value or just an abbreviation of novus, new (1968:419). Conformably, we label this new lobe $\mathrm{U}_{n 1}$. This lobe also increases in size quickly and pushes the internally situated $U_{1}$ onto the umbilical seam (Fig. 11, No. 22/8, 9; Fig. 12, No. 28/3-6). Soon afterwards, $U_{4}$ arises between $U_{3}$ and $U_{1}$ (Fig. 11, No. 22/10; Fig. 12, No. 28/7). In specimen No. 28 , almost simultaneously a $U_{n 2}$ arises by fissure of the saddle between $U_{n 1}$ and $U_{1}$ (Fig. 12, No. $28 / 7,8$ ). In the other specimens it arises somewhat later, at the end of the third whorl (Fig. 11, No. $22 / 11$; Fig. 12, No. 4/3). In these three specimens, it develops less quickly than the $U_{4}$, which arises almost simultaneously. After this, the $U_{1}$ becomes trifid. The two saddles enclosing the $\mathrm{U}_{4}$ are very wide and soon become similar to $U_{n 1}$. Then the other lobes become trifid (Fig. 12, No. $4 / 5 \mathrm{ff}$.). Only the internal lobe remains bifid.

It is remarkable that the lateral lobe, which is the deepest and widest lobe in the primary suture, diminishes in size successively even from the second suture and always remains smaller than the $\mathrm{U}_{2}$ alongside it. This makes it appear like an adventitious lobe $A$, but its ontogenetic development clearly marks it as the lateral lobe.

The formula of the suture line is now $E L U_{2} U_{3} U_{4} U_{1} U_{n 2} U_{n 1} I$. From now on, the shape of the suture line changes only by increasing incisions, but not by addition of saddles and lobes (Fig. 12, No. 4/7).

Suture line. Discussion. - No significant differences were observed in the suture lines within our material, fitting in with the result of the statistical investigation of conch morphology.

However, there are some special features observable in the ontogenetic development of the suture line. These are the conspicuously small lateral lobe and the formation of $\mathrm{U}_{n 1}$ and $\mathrm{U}_{n 2}$.

Plate 1. Figs. 1-5: Deforred specimens of Aristoptychites kolymensis (Kiparisova). Figs. 6-8: Deformed specimens of Aristoptychites in cross section. 
Triassic ammonite from Botneheia 71

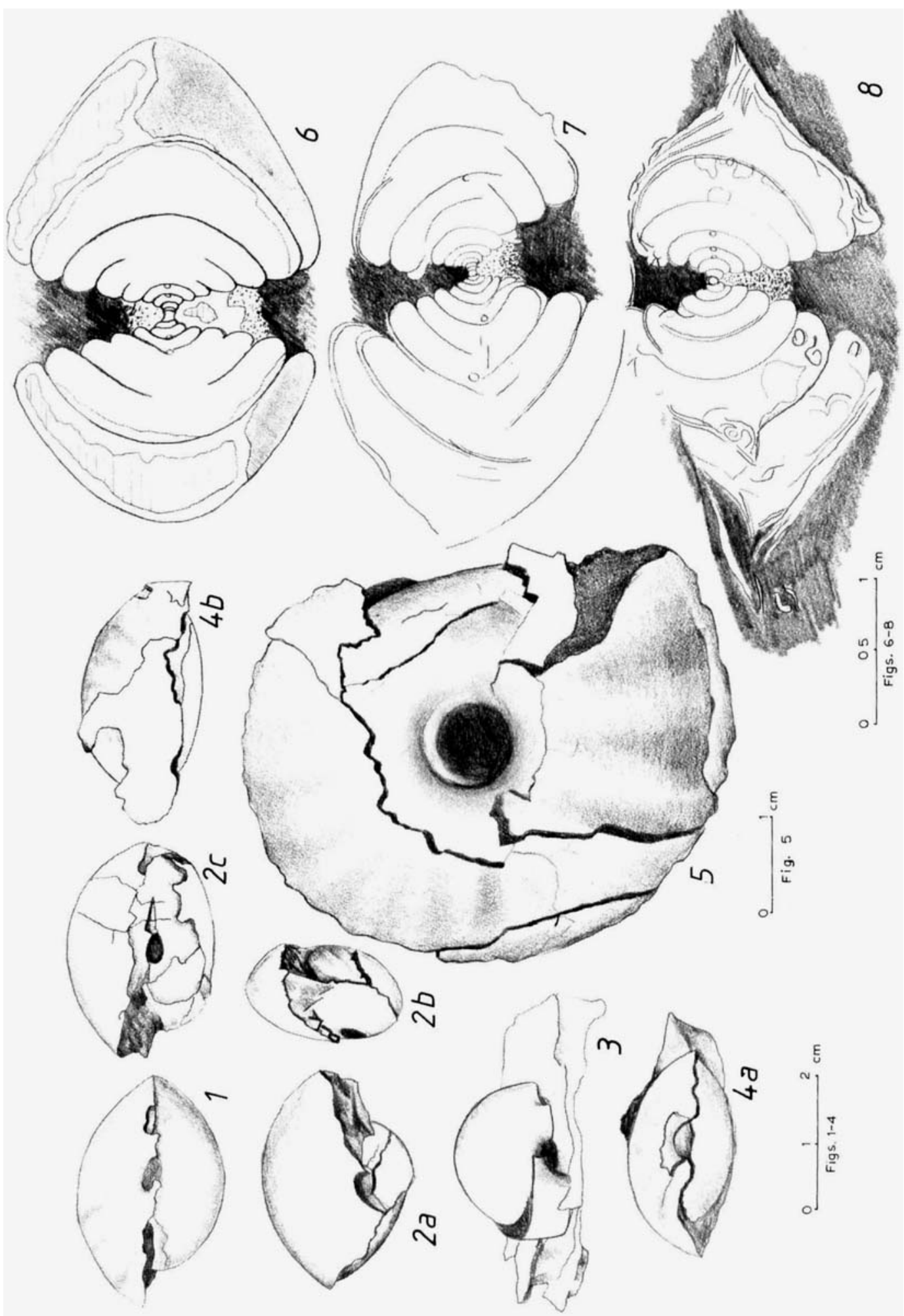




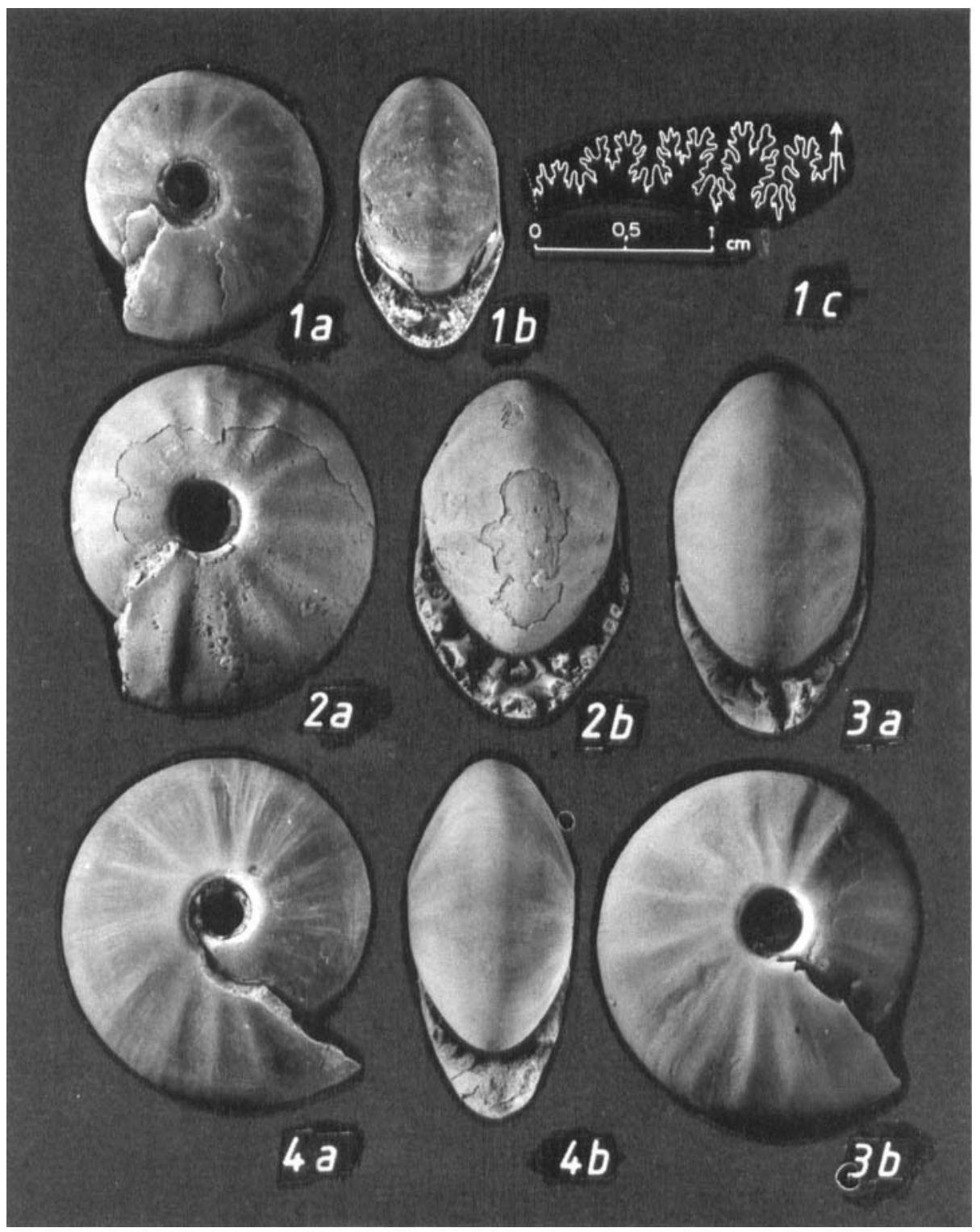

Plate 2. Aristoptychites kolymensis (Kiparisova). Figs. 1-4: Various modifications. Nat. size.

Wiedmann \& Kullmann (1981) published the suture line of Sturia Mojsisovics which, according to Arkell et al. (Treatise 1957) should be placed in the family Ptychitidae. It shows the $\mathrm{U}_{3}$ as a sutural lobe (Fig. 18); Wiedmann \& Kullmann (1981) consider this sutural lobe as typical of the Ptychitaceae.

Again, the protoconch figured in Plate 3, Figs. $1-4$, differs from a picture given by Branco $(1880 / 1881)$. The protoconch figured there
(Ptychites sp. Triassic, Schreyer Alp), which is erroneously labelled latisellate in the legend, is angustisellate, according to the description and illustration. We suppose that, owing to some mistake, it does not belong to Ptychites at all.

The suture of Sturia is fundamentally different from that of Aristoptychites described here, and the protoconch figured by Branco does not correspond to that of our forms. These differences support a supposition mentioned by Wiedmann 
PLATE 3.

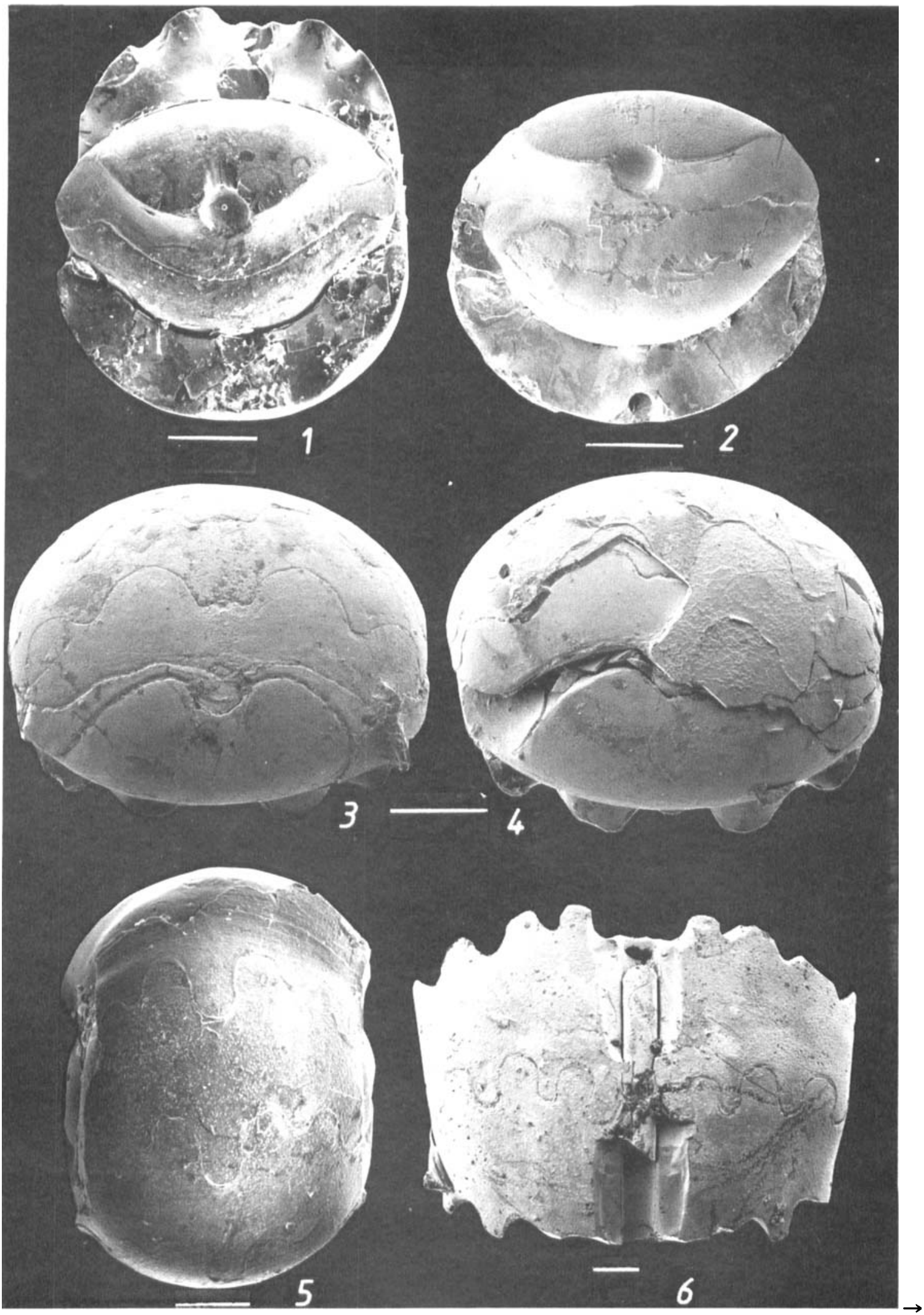


(pers. comm.) that the Ptychites group may be more heterogenic than hitherto thought (compare also Vavilov \& Alekseyev 1980).

Kullmann \& Wiedmann (1970:13) considered Ptychitidae and Arcestidae as possibly related. In fact, the development of the suture line described here is very similar to the development of Arcestes (Proarcestes) bicarinatus (Mstr.) as described and figured by Schindewolf (1968:821 ff.), which so far is the only known species with two $\mathrm{U}_{n}$-lobes. But there are two differences. The primary suture of Arcestes (Proarcestes) is already quinquelobate, and an adventitious (A-)lobe arises rather early. An Alobe in Triassic ammonoids is peculiar, no other occurrences are known.

In Fig. 13, the various sutures investigated in our material are combined to form a complete line of evolution, and drawn together with the evolutionary line of Proarcestes. We tried to place suture lines of about equal evolutionary stages side by side. The great similarity of the A-lobe of Proarcestes and the L-lobe of our material, which also remains rather small, is obvious. We feel that the appearance of an A-lobe is too sudden and thus the interpretation as an L-lobe is more plausible. In our interpretation, the element named L-lobe by Schindewolf would be $\mathrm{U}_{2}$, giving the complete formula $E_{2} U_{2} U_{3} U_{4} U_{1} U_{n 2} U_{1} I$ exactly that of our Aristoptychites. It seems necessary, therefore, to check the evolution of the Arcestes suture line, more so, since Schindewolf himself was not absolutely certain of his interpretation, owing to the bad state of preservation of his material (Schindewolf 1968:822).

Plate 3. Figs. 1-6: Aristoptychites kolymensis (Kiparisova). Fig. 1: Protoconch with part of the first whorl. Caecum and complete prosuture well visible. Fig. 2: Protoconch with part of the first whorl. Fig. 3: Part of the protoconch with external part of the prosuture and caecum, in addition external part of the primary suture and the following two suture lines. Fig. 4: Part of protoconch, first chamber broken out (between prosuture and primary suture). Also visible are parts of the next two sutures, covered by the dorsal (= inner) shell of the second whorl; visible on it are the internal lobe, the $U_{1}$, and between them a saddle with beginning $U_{n 1}$. Fig. 5: View of the dorsal inner side of the shell of the second whorl resting on the first whorl a little in front of the well visible nepionic constriction. Well recognisable are the internal lobe, the $U_{1}$ at the umbilical rim and in between the $U_{n 1}$ which is well developed here. Fig. 6: External view of two chambers close to the end of the second whorl. Siphuncle free. Well visible are E, $L$ (small), $U_{2}, U_{3}$.

\section{Summary ând conclusions}

A large number of possibly immature specimens of the genus Aristoptychites from a single horizon (uppermost part of the Daonella shales, Botneheia, on Spitsbergen) originally collected in search of interesting details within their living chambers, are systematically investigated. They were embedded in calcareous nodules formed at a rather late diagenetic stage at which the living chambers were already crushed. The nodules contain hardly any other fossils besides Aristoptychites and the bivalve Daonella and seem to signify extreme living conditions.

The Aristoptychites fauna is found to represent only one fairly variable species which is restricted to this very horizon.

The suture line of the species is characterized by possession of two additional $\mathrm{U}_{n}$-lobes, a feature in common with Arcestes (Proarcestes) bicarinatus (Münster) as described and interpreted by Schindewolf (1968) suggesting affinities between Ptychitidae and Arcestidae. Evidence is produced in favour of Tozer's (1981) subdivision of the family Ptychitidae represented in the Treatise (1957).

Acknowledgements. - Our investigations in the field as well as in the laboratory were made possible by grants from the Deutsche Forschungsgemeinschaft. This is gratefully acknowledged. For interesting and fruitful discussions we thank Dr. Wolfgang Weitschat (Hamburg) and Prof. Dr. Jobst Wiedmann (Tübingen). Lehmann is also grateful to Hans-Jürgen Lierl (Hamburg) for his untiring and cheerful cooperation during our collecting expeditions to Spitsbergen.

\section{References}

Birkelund, T. 1967: Submicroscopic shell structures in early growth-stage of Maastrichtian ammonites (Saghalinites and Scaphites). Medd. dansk geol. Foren. 17(1), 90-101.

Branco, W. 1880/81: Beiträge zur Entwicklungsgeschichte der fossilen Cephalopoden. Paläontographica, 27, Theil II, 20 81. Taf. 5, Fig. 1a, b.

Buchan, S. H., Challinor, A., Harland, W. B. \& Parker, J. R. 1965: The Triassic Stratigraphy of Svalbard. Nor. Polarinst. Skr. 135.93 pp.

Frebold, H. 1931: Fazielle Verhältnisse des Mesozoikums im Eisfjordgebiet Spitzbergens. Ein Beitrag zur Entwicklungsgeschichte des Skandiks. 1. Teil. Skrifter om Sualbard og Ishavet 37, $94 \mathrm{pp}$.

Frebold, H. 1935: Geologie von Spitzbergen, der Băreninsel, des König-Karl- und Franz-Joseph-Landes. In: Geologie der Erde. Gebr. Borntraeger, Berlin.

Haarländer, W. 1952: Die Spirale der Ammonoidea. Geol. Bl. NO-Bayern 2, 1-15. 
Kiparisova, L. D. 1937: Fauna triassischer Ablagerungen im östlichen Teil der sowjetischen Arktis. Trans. Arctic Inst. 91, 135-256. Leningrad.

Kulimann, J. \& Wiedmann, J. 1970: Significance of sutures in phylogeny of Ammonoidea. Paleont. Contr. Univ. Kansas 47. $32 \mathrm{pp}$.

Mojsisovics, E. v. 1882: Die Cephalopoden der Mediterranen Triasprovinz. Abh. Geol. Reichsanst. Wien 10. $250 \mathrm{pp}$.

Mojsisovics, E. v. 1885: Struktur des Sipho bei triadischen Ammoneen. Neues Jahrb. Min., II. 154 ff., Taf. VII, Fig. 2.

Schindewolf, O. H. 1961-1968: Studien zur Stammesgeschichte der Ammoniten. Abh. Akad. Wiss. Lit. Mainz, Math.-nat. $K l$.

Tozer, E. T. 1961: Triassic stratigraphy and faunas, Queen Elizabeth Islands, Arctic Archipelago. Mem. Geol. Surv. Can. 316, 92-96.

Tozer, E. T. 1981: Triassic Ammonoidea: classification, evolution and relationship with Permian and Jurassic forms. In
The Ammonoidea, House, M. R. \& Senior, M. R. (eds.): The Systematics Association, spec. Vol. 18, 65-100. Academic Press, London.

Tozer, E. T. \& Parker, J. R. 1968: Notes on the Triassic biostratigraphy of Svalbard. Geol. Mag. 105(6), 526-542.

Treatise on Invertebrate Paleontology, Part L. Geol. Soc. America and Univ. Kansas Press, 1957.

Vavilov, M. N. \& Alekseyev, S. N. 1980: Ontogenetic development and internal structure of the middle Triassic genus Aristoptychites. Paleontological Journal.

Weitschat, W. \& Lehmann, U. 1978: Biostratigraphy of the uppermost part of the Smithian Stage (Lower Triassic) at the Botneheia, W. Spitsbergen. Mitt. Geol. Paläont. Inst. Univ. Hamburg 48, 85-100.

Wiedmann, J. \& Kullmann, J. 1981: Ammonoid sutures in ontogeny and phylogeny. In The Ammonoidea, House, $\mathbf{M}$. R. \& Senior, J. R. (eds.): The Systematics Association, spec. Vol. 18, 215-255. Academic Press, London. 